\title{
Genetics of neuromuscular fetal akinesia in the genomics era
}

\author{
Sarah Jane Beecroft, ${ }_{1}^{1,2}$ Marcus Lombard, ${ }^{1,2}$ David Mowat, ${ }^{3}$ Catriona McLean, ${ }_{1}^{4}$ \\ Anita Cairns, ${ }^{5}$ Mark Davis, ${ }^{6}$ Nigel G Laing, ${ }^{1,2}$ Gianina Ravenscroft ${ }^{1,2}$
}

${ }^{1}$ Centre for Medical Research, Faculty of Health and Medical Sciences, The University of Western Australia, Perth, Western Australia, Australia ${ }^{2}$ Harry Perkins Institute of Medical Research, QQ Block, QEIl Medical Centre, Nedlands, Western Australia, Australia ${ }^{3}$ Centre for Clinical Genetics, Sydney Children's Hospital, Sydney, New South Wales, Australia

${ }^{4}$ Victorian Neuromuscular Laboratory, Alfred Health, Melbourne, Victoria, Australia ${ }^{5}$ Department of Neurology, Lady Cilento Children's Hospital, Brisbane, Queensland, Australia ${ }^{6}$ Neurogenetics Laboratory, Department of Diagnostic Genomics, PP Block, QEll Medical Centre, Nedlands, Western Australia, Australia

\section{Correspondence to}

Dr Gianina Ravenscroft, Centre for Medical Research, Faculty of Health and Medical Sciences, The University of Western Australia, Perth, WA 6009, Australia; gina.ravenscroft@ uwa.edu.au

$\mathrm{SJB}$ and $\mathrm{ML}$ contributed equally.

Received 17 January 2018

Revised 22 March 2018

Accepted 19 April 2018

Published Online First

29 June 2018

Check for updates

To cite: Beecroft $S J$,

Lombard M, Mowat D, et al.

$J$ Med Genet

2018:55:505-514

\section{ABSTRACT}

Fetal hypokinesia or akinesia encompasses a broad spectrum of disorders, united by impaired movement in utero. Often, the underlying aetiology is genetic in origin, affecting part of the neuromuscular system. The affordable and high-throughput nature of nextgeneration DNA sequencing has led to an explosion in disease gene discovery across rare diseases, including fetal akinesias. A genetic diagnosis has clinical utility as it may affect management and prognosis and informs recurrence risk, facilitating family planning decisions. More broadly, knowledge of disease genes increasingly allows population-based preconception carrier screening, which has reduced the incidence of recessive diseases in several populations. Despite gains in knowledge of the genetics of fetal akinesia, many families lack a genetic diagnosis. In this review, we describe the developments in Mendelian genetics of neuromuscular fetal akinesia in the genomics era. We examine genetic diagnoses with neuromuscular causes, specifically including the lower motor neuron, peripheral nerve, neuromuscular junction and muscle.

\section{INTRODUCTION}

Fetal hypokinesia or akinesia encompasses a broad spectrum of disorders with the unifying feature of reduced or absent fetal movement, which results in a variety of secondary defects. ${ }^{1}$ For simplicity, we will from here on refer to these diseases as fetal akinesias. This group contains several overlapping entities, ranging in severity from distal arthrogryposis, multiple pterygium syndrome and arthrogryposis multiplex congenita (AMC), to the most severe, fetal akinesia deformation sequence (FADS). ${ }^{1}$ Features vary depending on when fetal movement was impaired. The phenotype may be further complicated by abnormalities associated with the underlying cause of the akinesia. However, common features include subcutaneous oedema, fetal hydrops, lung hypoplasia, rocker-bottom feet, craniofacial anomalies (particularly cleft palate, retromicrognathia), intrauterine growth restriction and poor muscle bulk. ${ }^{1}$ Landmark studies demonstrated reduced fetal movement is responsible for the main clinical features, highlighting the need for adequate fetal movement in normal development. ${ }^{23}$

The underlying defect can be genetic or environmental. The aetiology is generally categorised into muscular disorders, neurological disorders (central and/or peripheral, and neurometabolic), connective tissue disorders, fetal vascular compromise, uterine space limitations and maternal diseases or drug use. ${ }^{1}$ This review is an update from Ravenscroft $e t$ $a l^{1}$ covering discoveries in monogenic fetal akinesia disorders with neuromuscular causes. ${ }^{1}$ Specifically, we focus on conditions affecting the lower motor neuron, peripheral nerves, neuromuscular junction (NMJ) and skeletal muscles. As per the 2011 review, restrictive dermopathies and primary brain abnormalities are excluded. However, it is important to note that brain abnormalities are often difficult to distinguish from primary neuromuscular causes of fetal akinesia because the clinical features can overlap considerably. Genes recently associated with central forms of fetal akinesia include PI4KA, PDHA1 and SLC6A9. ${ }^{4-6}$ Table 1 summarises new discoveries since the 2011 review.

Since 2011, there has been an explosion in disease gene discovery, powered by affordable massively parallel next-generation sequencing (NGS). New genotype-phenotype correlations are blurring the boundaries between what were once considered distinct entities. ${ }^{78}$ This trend extends beyond fetal akinesia, across neuromuscular diseases as a whole. ${ }^{8}$ Defining the genetic and phenotypic spectra of fetal akinesias is significant for patients and clinicians, as it facilitates a genetic diagnosis. ${ }^{89}$ This is vital, as clinical diagnosis of fetal akinesia disorders mid-gestation is especially challenging; ultrasonography has limited diagnostic utility, and clinical information such as intellectual ability is not available. ${ }^{10-12}$ Postnatal diagnosis is hampered by the clinical heterogeneity of the fetal akinesia spectrum. ${ }^{10}$ Beyond immediate clinical utility, genetic diagnosis clarifies family genetic implications and allows consideration of reproductive options in 'high risk' cases (ie, preimplantation genetic diagnosis, prenatal genetic diagnosis). Paediatric precision medicine has the potential to resolve heterogeneity, limit unnecessary testing and spare parents and patients from the diagnostic odyssey. ${ }^{13}$ Rapid NGS-based testing for genetic diseases showed significant success in neonatal and paediatric intensive care units, allowing reduction of morbidity and mortality via precision interventions. ${ }^{13} 14$ However, this requires large quantities of high-quality DNA from the affected offspring. Access to sufficient quantity/quality of material is often limited, particularly in cases of fetal demise. ${ }^{12}$ An alternative approach is parental exome sequencing, which searches for rare, heterozygous variants occurring in the same gene in both parents. Despite being unable to identify de novo variants, this method had an overall success rate of 
Table 1 Summary of neuromuscular fetal akinesia genetics, 2011 and 2018

\begin{tabular}{|c|c|c|c|}
\hline Gene symbol & MIM & Mode of inheritance & Fetal disease entity \\
\hline \multicolumn{4}{|c|}{ Genes involved in motor neuron development and survival } \\
\hline SMN1 & 600354 & AR & SMA, FADS \\
\hline ERBB3 & 190151 & AR & LCCS2 \\
\hline GLE1 & 603371 & AR & LCCS1, LAAHD, non-lethal arthrogryposis \\
\hline PIP5K1C & 606102 & $A R$ & LCCS3 \\
\hline UBE1 & 314370 & $\mathrm{XL}$ & XL-SMA \\
\hline \multicolumn{4}{|c|}{ Genes involved in combined central and peripheral nervous system defects } \\
\hline ASCC1 and TRIP4 & 614215,604501 & AR & Congenital bone fractures 1 and 2 \\
\hline CNTNAP1 & 602346 & AR & LCCS7 \\
\hline LGI4 & 608303 & AR & AMC, neurogenic with myelin defect \\
\hline \multicolumn{4}{|c|}{ Genes encoding components of the peripheral nervous system } \\
\hline PIEZO2 & 613629 & $A D, A R^{*}$ & MWKS, DA3, DA5, DAIPT \\
\hline \multicolumn{4}{|c|}{ Genes encoding components of the neuromuscular junction } \\
\hline CHRNA1 & 100690 & AR & Lethal multiple pterygium syndrome \\
\hline CHRND & 100720 & AR & AMC/CMS with fetal akinesia, FADS \\
\hline CHRNG & 100730 & AR & Lethal and EV MPS \\
\hline CNTN1 & 600016 & AR & CM with fetal akinesia \\
\hline DOK7 & 610285 & AR & FADS \\
\hline SYNE1 & 608441 & AR & AMC with fetal akinesia \\
\hline RAPSN & 601592 & AR & AMC, FADS \\
\hline MUSK & 601296 & AR & CMS9, FADS \\
\hline LMNA & 150330 & $A R$ & LGMD1B with fetal akinesia \\
\hline MTM1 & 300415 & $\mathrm{XL}$ & MTM with fetal akinesia \\
\hline NEB & 161650 & AR & FADS \\
\hline RYR1 & 180901 & $A D, A R^{*}$ & FADS, CRM with fetal akinesia, MPS \\
\hline TPM2 & 190990 & $A D, A R^{*}$ & EV MPS, DA1, DA2B, NEM 4, cap myopathy 2 \\
\hline TNNI2 & 191043 & $A D$ & $\mathrm{DA} 1, \mathrm{DA} 2 \mathrm{~B}$ \\
\hline TNNT3 & 600692 & $A D$ & $\mathrm{DA} 1, \mathrm{DA} 2 \mathrm{~B}$ \\
\hline CACNA1S & 114208 & $A D, A R$ & Congenital myopathy, fetal akinesia \\
\hline DNM2 & 602378 & $A D, A R^{*}$ & LCCS5 \\
\hline FKTN & 607440 & AR & MDDGA4 \\
\hline SCN4A & 603967 & $A D, A R^{*}$ & Congenital myopathy, fetal hypokinesia \\
\hline VMA21 & 300913 & $\mathrm{XL}$ & XMEA \\
\hline \multicolumn{4}{|c|}{ Genes encoding fetally expressed myostructural proteins } \\
\hline MYH3 & 160270 & $A D$ & DA2A, DA2B, DA8, MPS \\
\hline MYH8 & 160741 & $A D$ & CC-DA7, DA7 \\
\hline UTRN & 128240 & & Arthrogryposis with fetal akinesia \\
\hline KLHL4O & 615340 & AR & NEM8, fetal akinesia \\
\hline KLHL41 & 607701 & AR & NEM9, fetal akinesia \\
\hline LMOD3 & 616112 & AR & NEM10, fetal akinesia \\
\hline MYOD1 & 159970 & AR & Lethal fetal akinesia \\
\hline MYBPC1 & 160794 & $A D, A R^{*}$ & DA1B, LCCS4 \\
\hline TTN & 188840 & $A D, A R^{*}$ & Cardiomyopathy, muscular dystrophy, fetal akinesia \\
\hline
\end{tabular}


Table 1 Continued

\begin{tabular}{clll}
\hline Gene symbol & MIM & Mode of inheritance & Fetal disease entity \\
\hline ZBTB42 & 613915 & AR & LCCS6 \\
Other genes & & & \\
\hline FGFR2 & 176943 & AD & FADS \\
\hline GBE1 & 607839 & AR & GSD-IV/FADS \\
DPAGT1 & 191350 & AR & Congenital disorder of glycosylation, type Ij \\
\hline
\end{tabular}

Plain text indicates information from 2011 review.

Bold text indicates new information from 2018 review. Genes with asterisks manifest severe fetal akinesia phenotypes only with recessive inheritance.

$A D$, autosomal dominant; $A M C$, arthrogryposis multiplex congenita; $A R$, autosomal recessive; $C C$, Carney complex; $C M$, congenital myopathy; $C M S$, congenital myasthenic syndrome; CNM, centronuclear myopathy; CRM, core-rod myopathy; DA, distal arthrogryposis; DAIPT, arthrogryposis, distal, with impaired proprioception and touch; DM, myotonic dystrophy; EV, Escobar variant; FADS, fetal akinesia deformation sequence; GSD-IV, glycogen storage disease type IV; LAAHD, lethal arthrogryposis with anterior horn cell disease; LCCS, lethal congenital contracture syndrome; LGMD1B, limb-girdle muscular dystrophy type 1B; MDDG, muscular dystrophy-dystroglycanopathy; MPS, multiple pterygium syndrome; MTM, myotubular myopathy; MWKS, Marden-Walker syndrome; NA, not available; NEM, nemaline myopathy; SMA, spinal muscular atrophy; WWS, WalkerWarburg syndrome; XL, X linked; XMEA, X linked myopathy with excessive autophagy.

$52 \%$ in a cohort of 50 couples. $^{12}$ Although various sequencing approaches offer hope of rapid and non-invasive diagnosis, cost, feasibility and ethical issues require consideration before routine implementation of these in a diagnostic setting. ${ }^{15}$

\section{GENES INVOLVED IN MOTOR NEURON DEVELOPMENT AND SURVIVAL ERGIC1}

In 2017, Reinstein et al performed a genetic investigation of a large Israeli Arab family clinically described by Lebenthal et al. ${ }^{1617}$ Forty affected individuals were examined and diagnosed with AMC neurogenic type (MIM 208100) specifically affecting the lower motor neurons. ${ }^{17}$ Key features included congenital equinovarus and flexion contractures at the knees and elbows with muscle hypotrophy around the involved joints. One patient had severe mental retardation. A neuropathic cause was supported by electrophysiological studies and neurological examination. Exome sequencing revealed a homozygous missense mutation in ERGIC1 (endoplasmic reticulum-Golgi intermediate compartment 1). ${ }^{17}$ ERGIC1 encodes a putative transmembrane protein with a role in transport between the endoplasmic reticulum and the Golgi apparatus. ${ }^{17}$

\section{GLE1}

Biallelic GLE1 (RNA export mediator; MIM 603371) mutations were initially shown to cause two lethal diseases in the Finnish population (lethal congenital contracture syndrome 1 (LCCS1), MIM 253310; and lethal arthrogryposis with anterior horn cell disease (LAAHD), MIM 611890). ${ }^{1}$ Previously, GLE1 mutations were described almost exclusively in Finnish patients. Homozygosity for the Fin major $_{\text {mution caused LCCS1, while compound }}$

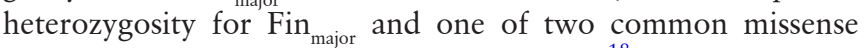
mutations caused the slightly milder LAAHD. ${ }^{18}$ However, recent reports describe four non-Finnish patients surviving into childhood, prompting debate if these cases constitute a new clinical entity or a phenotypic expansion. ${ }^{18-20}$ One patient died of respiratory insufficiency at age 4 ; three patients are alive at 26 months, 4 years and 12 years. ${ }^{18-20}$ Finding that patients without the 'Finnish' mutations can survive beyond infancy suggests disease severity is mutation-dependent. ${ }^{18}$

\section{TUBB2B}

TUBB2B (MIM 612850) encodes beta-2B tubulin, a microtubule component. ${ }^{21}$ Dominant mutations cause complex cortical dysplasia with other brain malformations (MIM 610031). Laquerriere et $a l^{22}$ added de novo dominant FADS as a severe manifestation of this phenotypic spectrum. Ultrasound at 14 weeks' gestation revealed complete fetal akinesia; pregnancy was terminated at 15 weeks. The fetus showed multiple brain abnormalities, cleft palate, lung hypoplasia, dilated renal pelvis, global amyotrophy and severe spinal cord hypoplasia. Motoneurons were almost undetectable in the anterior and posterior horns. ${ }^{22}$

\section{GENES INVOLVED IN COMBINED CENTRAL AND PERIPHERAL NERVOUS SYSTEM DEFECTS ASCC1 and TRIP4}

The tetrameric ASC-1 transcriptional cointegrator complex comprised four subunits: subunit 1 (ASCC1; MIM 614215), subunit 2 (ASCC2; MIM 614216), subunit 3 (ASCC3; MIM 614217) and thyroid hormone receptor interactor 4 (TRIP4; MIM 604501). ${ }^{23}$ This complex may act in neuromuscular unit development via myogenic differentiation and growth regulation. $^{2324}$ In 2016, four families with congenital bone fractures 1 (MIM 616866) were described with recessive lossof-function TRIP4 mutations, while one family with congenital bone fractures 2 (MIM 616867) showed biallelic ASCC1 lossof-function mutations. ${ }^{23}{ }^{24}$ Consistent features included fetal hypokinesia, lack of muscle contraction on electrical nerve stimulation, axonal neuropathy and requirement for ventilator assistance. Muscle biopsy showed features suggestive of spinal muscular atrophy. One TRIP4 patient showed apoptotic alpha-motoneurons, while sural nerve biopsy of two ASCC1 patients showed unmyelinated axon loss. All patients died of respiratory distress before the age of $2 .^{23}$ In 2017, a second ASCC1 case was described, supporting this as a human disease gene. $^{25}$

\section{CNTNAP1}

CNTNAP1 (contactin-associated protein 1; MIM 602346) encodes the contactin-associated protein CASPR, which is involved in the correct formation of paranodal junctions in myelinated axons. ${ }^{26} 27$ Laquérriere et al $^{27}$ reported homozygous frameshift CNTNAP1 mutations in seven patients from four consanguineous families. Five of the patients had fetal akinesia. At birth, patients had severe motor paralysis, leading to death within 2 months. Features included markedly decreased nerve conduction velocity, widening of the nodes of Ranvier and thin myelin sheaths in the sciatic nerve. ${ }^{27}$ This entity was designated lethal congenital contracture syndrome 7 (MIM 616286). Later, Hengel et $a l^{26}$ described five patients from two families with biallelic truncating CNTNAP1 mutations causing severe hypomyelinating leucodystrophy with peripheral neuropathy. 


\section{LGI4}

LGI4 regulates peripheral nerve myelination. ${ }^{28}$ Xue et $a l^{28}$ described nine patients with AMC from four families with biallelic loss-of-function LGI4 mutations (leucine-rich repeat LGI family member 4; MIM 608303). This entity is defined as arthrogryposis multiplex congenita, neurogenic, with myelin defect (MIM 617468). Features included clubfoot, camptodactyly, retrognathia and pulmonary hypoplasia. One patient survived past infancy. At age 4, he has dysmorphic features, verbal developmental delay, hypotonia, scoliosis and seizures. Muscle biopsy was suggestive of spinal anterior horn cell dysgenesis, but the sciatic nerve of one patient showed hypomyelination. $^{28}$ Lgi4-deficient mice also display arthrogryposis and peripheral hypomyelination. ${ }^{28}$

\section{GENES ENCODING COMPONENTS OF THE PERIPHERAL NERVOUS SYSTEM ADCY6}

Recessive ADCY6 mutations (adenylyl cyclase 6; MIM 600294) cause lethal congenital contracture syndrome 8 (LCCS8; MIM 616287). Laquérriere et al described two consanguineous siblings with reduced fetal movements and distal joint contractures. Postnatally, the infants had areflexia, severe motor paralysis and respiratory distress leading to death within 3 months of birth. ${ }^{27}$ No response was found on motor nerve conduction velocity testing. Electron microscopy showed no myelinated axons despite normal Schwann cell distribution. ${ }^{27}$ ADCY6 synthesises cyclic AMP, although its role in myelin protein expression in the peripheral nervous system is not fully understood. ${ }^{27}$ Knockdown in zebrafish showed absence of myelin basic protein from the peripheral nervous system. ${ }^{27}$

\section{ADGRG6 (GPR126)}

Ravenscroft et al described four individuals from three consanguineous families variably displaying polyhydramnios, ulnar deviation of hands, diaphragmatic atrophy and pterygia. Ultrasound findings were abnormal from as early as 16 weeks' gestation. ${ }^{29}$ The phenotype was labelled lethal congenital contracture syndrome 9 (LCCS9; MIM 616503). All patients harboured homozygous loss-of-function mutations in ADGRG6 (adhesion G protein-coupled receptor G6; MIM 612243). Gpr126 $6^{-1-}$ mice also display a lethal arthrogryposis phenotype. ${ }^{30}$ ADGRG6 is critical for myelination of the peripheral nervous system. ${ }^{30}$ Patients' peripheral nerves showed almost complete absence of myelin basic protein. ${ }^{29}$

\section{ECEL1}

Biallelic mutations in ECEL1 (endothelin-converting enzymelike 1; MIM 605896) cause distal arthrogryposis type 5D (DA5D; MIM 615065). ${ }^{31}$ McMillin et al differentiated this from DA5 (see PIEZO2 below) on the basis of the ECEL1 cohort having ptosis but not ophthalmoplegia. ${ }^{31}$ The consensus phenotype includes hand and foot camptodactyly, wrist and knee contractures, clubfoot, short neck, round-shaped face, and bulbous nose. ${ }^{33}$ Variable features include micrognathia, tongue atrophy, astigmatism and hip dislocation. ${ }^{33}$ Muscle biopsies from two affected siblings showed features suggestive of centronuclear myopathy, although further studies are needed to confirm this finding. ${ }^{33}$ Mouse models demonstrated that Dine (ECEL1 homologue) is required for normal arborisation of motor axons after innervation, and subsequent NMJ formation. ${ }^{3435}$ Additionally, disruption of Dine impaired differentiation of immature Schwann cells. ${ }^{34}$
GLDN

Maluenda et $a l^{36}$ identified six individuals with AMC, marked polyhydramnios and fetal akinesia at 27-32 weeks' gestation, despite unremarkable earlier ultrasounds. Features variably included intrauterine growth retardation, knee and elbow contractures, camptodactyly and retrognathia. ${ }^{36}$ Electron microscopy of one patient's sciatic nerve showed reduced numbers of myelinated fibres and a significant increase in nodal length. Biallelic mutations were identified in the gene encoding gliomedin (GLDN; MIM 608603), which is an adhesion molecule involved in the formation of the nodes of Ranvier and development of the peripheral nervous system. ${ }^{36}$ This disorder is designated lethal congenital contracture arthrogryposis 11 (LCCS11; MIM 617194). However, a 2017 study found four patients with recessive GLDN mutations who survived into late adolescence with intensive care, showing LCCS11 is not necessarily congenitally lethal. $^{37}$

\section{PIEZO2}

PIEZO2 is a mechanically activated non-selective cation channel essential for mechanotransduction in certain tissues. ${ }^{38}$ PIEZO2 (Piezo-type mechanosensitive ion channel component 2; MIM 613629) mutations have been implicated in both dominant and recessive disease. Dominant mutations cause three overlapping phenotypes: Marden-Walker syndrome (MIM 248700), distal arthrogryposis type 3 (Gordon syndrome; MIM 114300) and distal arthrogryposis type 5 (DA5; MIM 108145). ${ }^{38-40}$ These entities are distinguished by mental retardation, cleft palate and ocular abnormalities, respectively. ${ }^{39}$ However, these may be variable presentations of the same disorder. ${ }^{40} \mathrm{~A}$ dominant negative mechanism has been proposed, with mutants impairing multimer formation. ${ }^{41}$ Recessive loss-of-function mutations in PIEZO2 cause autosomal recessive DA with impaired proprioception and touch (MIM 613629). ${ }^{41-43}$ Key features include dysmetria, muscle atrophy, progressive contractures and impaired mechanosensation causing ataxia. Reduced fetal movements and congenital hip dysplasia have also been described. ${ }^{42}$ Although Piezo2 knockout is perinatal lethal in mice, human life expectancy is normal. It has been suggested that humans with homozygous loss-of-function alleles may produce some functional PIEZO2 through alternative splicing. ${ }^{44}$ This may explain the relatively mild phenotype compared with mice.

\section{GENES ENCODING COMPONENTS OF THE NMJ MUSK}

MUSK (muscle associated receptor tyrosine kinase; MIM 601296) encodes a muscle-specific receptor tyrosine kinase (MuSK) critical for formation and maintenance of postsynaptic NMJs. ${ }^{45}$ Recessive MUSK mutations cause postsynaptic congenital myasthenic syndrome (CMS), with severe cases resulting in fetal akinesia. A founder effect was discovered within a Dutch genetic isolate of 10 families, revealing a novel homozygous p.Ile 575Thr substitution in all 14 cases (carrier frequency $8 \%$ ). ${ }^{45}$ The mutation causes abnormal acetylcholine receptor clustering and synaptogenesis. ${ }^{45}$ Wilbe $e t ~ a l^{46}$ discovered a second founder effect in Sweden. One Swedish couple had five affected fetuses that all harboured a homozygous truncating mutation. ${ }^{46}$

\section{SLC18A3}

SLC18A3 (solute carrier family 18 member A3; MIM 600336) encodes vesicular acetylcholine transporter (VAChT), which packages acetylcholine into presynaptic vesicles. ${ }^{47}$ Biallelic mutations cause presynaptic CMS, with severe presentations 
including fetal akinesia. ${ }^{47}$ Aran et al described two brothers with retrognathia, severe hypotonia, bilateral dislocated hips, bilateral undescended testes, micropenis and marked hirsutism. The first sibling died 5 days postnatally due to respiratory insufficiency. The second sibling has profound global developmental disability, delayed brain myelination, extreme hypotonia and progressive microcephaly at 4.5 years old. Western blot suggested the mutant VAChT protein undergoes post-translation degradation. This loss-of-function might explain the severe phenotype in this family. $^{47}$

\section{UNC50}

A single lethal AMC case with a homozygous frameshift deletion in UNC50 (inner nuclear membrane RNA-binding protein; MIM 617826) has been described. ${ }^{48}$ Ultrasound showed AMC and subcutaneous oedema before a stillborn male infant was spontaneously delivered at 28 weeks with pulmonary hypoplasia and limb muscular atrophy. ${ }^{48}$ Muscle biopsy showed some atrophic fibres and areas of myofibrillar disorganisation. Although publication of a second family is required for confirmation of pathogenicity, UNC50 is a candidate for similar cases. ${ }^{48}$ UNC50 is involved in acetylcholine receptor trafficking. Introduction of an equivalent mutation in Caenorhabditis elegans caused loss of acetylcholine receptor expression at the NMJ. ${ }^{48}$

\section{GENES ENCODING ADULT SKELETAL MUSCLE PROTEINS CACNA1S}

Dominant mutations in L-type voltage-dependent $\mathrm{Ca}^{2+}$ channel, alpha-1a subunit (CACNA1S; MIM 114208) are well known to cause hypokalaemic periodic paralysis, type 1 (MIM 170400) and susceptibility to malignant hyperthermia (MIM 601887). ${ }^{49}$ Recently, dominant and recessive CACNA1S mutations were shown to cause congenital myopathy with particular morphological hallmarks, with fetal akinesia being the most severe manifestation. ${ }^{49}$ The described 11 patients presented with congenital or early-onset hypotonia, facial weakness, delayed motor milestones and progressive muscle weakness. Respiratory function ranged from severe impairment to normal. Muscle biopsy showed sarcoplasmic reticulum dilatation, internal nuclei and areas of myofibrillar disorganisation in some samples. Three patients had decreased fetal movement and breech presentation. Of these, one had a heterozygous de novo mutation and two were compound heterozygous. Regardless of inheritance pattern, western blot and RT-PCR studies suggested reduced protein levels, possibly through reduced stability or inability to form complexes. ${ }^{49}$

\section{DNM2}

Heterozygous DNM2 mutations (MIM 602378) cause comparatively mild disorders including Charcot-Marie-Tooth disease and centronuclear myopathy. ${ }^{50-53}$ Koutsopoulos et al recently identified a novel homozygous mutation in three consanguineous patients with fetal hypokinesia, polyhydramnios, multiple contractures, brain and retinal haemorrhages, and thin bones. ${ }^{53}$ Postnatally, the patients showed respiratory insufficiency and absent reflexes. Electromyogram- in one case showed possible myopathic or lower motor neuron signs. The phenotype is labelled lethal congenital contracture syndrome 5 (MIM 615368). DNM2 acts in muscle and axonal maintenance. ${ }^{53}$ Morpholino knockdown of $d n m 2$ in zebrafish showed mild misalignment of myofibres and altered blood vessel morphology, but muscle innervation was normal. The authors concluded the aetiology was not neuropathic.

\section{FKTN}

FKTN (fukutin, MIM 607440) encodes a putative glycosyltransferase enzyme of the same name. ${ }^{545}$ Recessive mutations cause a range of phenotypes via abnormal O-glycosylation of $\alpha$-dystroglycan, which reduces binding to extracellular matrix proteins. ${ }^{54-56}$ Three forms of muscular dystrophy-dystroglycanopathy have been attributed to FKTN: the most severe congenital form with structural brain and eye anomalies (MDDGA4; MIM 253800); a less severe congenital form without mental disability (MDDGB4; MIM 613152); and the milder limb-girdle form (MDDGC4; MIM 611588). ${ }^{55}$ Dilated cardiomyopathy with adult-onset muscle weakness and normal cognition has also been described (dilated cardiomyopathy 1X; MIM 611615). ${ }^{57}$ Severe MDDGA4 cases onset prenatally, such as those described by Chang et al. ${ }^{54}$ They describe a muscle biopsy from an MDDGA4-affected fetus, terminated at 15 weeks' gestation due to brain and heart abnormalities. The muscle was dystrophic, suggestive of $\alpha$-dystroglycan hypoglycosylation, and severe secondary merosin deficiency. ${ }^{54}$

\section{SCN4A}

SCN4A (MIM 603967) encodes the alpha subunit of the skeletal muscle voltage-gated sodium channel $\left(\mathrm{Na}_{\mathrm{v}} 1.4\right)$, which is critical for generation and propagation of the muscle action potential. ${ }^{58}$ Dominant gain-of-function mutations cause myotonia/ paramyotonia or periodic paralysis. ${ }^{59}$ Recessive loss-of-function mutations were more recently shown to cause congenital myopathy, with severity ranging from severe fetal hypokinesia to 'classical' congenital myopathy. ${ }^{59}$ Eleven individuals from six unrelated families were recently described. ${ }^{59}$ Seven patients presented with severe fetal hypokinesia, contractures, polyhydramnios and marked muscle hypoplasia. Of these patients, one survived for 5 hours neonatally, while all others died before or during birth (one pregnancy was terminated at 28 weeks). Each patient carried at least one mutation that completely inactivated the $\mathrm{Na}_{\mathrm{v}} 1.4$ channel. ${ }^{59}$ Muscle biopsies confirmed a myopathic process without specific structural abnormalities. ${ }^{59}$

\section{VMA21}

VMA21 (MIM 300913) encodes vacuolar ATPase (V-ATPase) assembly integral membrane protein VMA21, required for assembly and function of the V0 complex of the V-ATPase in the endoplasmic reticulum. ${ }^{60}$ Mutations in VMA21 cause $\mathrm{X}$ linked recessive myopathy with excessive autophagy (MIM 310440). Severe manifestations have congenital or prenatal onset. ${ }^{61} 62$ Five of seven affected males with congenital onset described by Yan et al did not survive infancy. ${ }^{61}$ However, no abnormalities were noted during pregnancy. A later case report expanded the phenotype to include micrognathia, short limbs and arthrogryposis detected on ultrasound. ${ }^{60}$ Sequencing revealed a novel in-frame deletion in the transmembrane domain. ${ }^{60}$

\section{GENES ENCODING FETALLY EXPRESSED MYOSTRUCTURAL PROTEINS \\ KLHL40}

Recessive mutations in KLHL40 (kelch-like 40; MIM 615340) cause severe nemaline myopathy (NEM8; MIM 615348), with features including fetal akinesia, contractures, fractures, respiratory failure and swallowing difficulties at birth. ${ }^{63}$ The cohort described by Ravenscroft et al had an average survival time of 5 months. ${ }^{63}$ Consistent with a loss-of-function mechanism, muscle biopsies showed absence of KLHL40 even in patients with two missense mutations. ${ }^{63}$ Knockdown of the 
zebrafish orthologues (Klhl40a/Klbl40b) caused disrupted muscle patterning, gaps between myofibres and widened Z-discs. ${ }^{63}$ Mouse knockouts echoed human nemaline myopathy features. ${ }^{64}$ KLHL 40 was shown to bind, stabilise and maintain expression of nebulin and LMOD3 $3{ }^{64}$ Absence of KLHL40 reduces the amount of these thin filament proteins, likely leading to the sarcomeric disarray and impaired muscle contractility. ${ }^{64}$

\section{KLHL41}

Gupta et al identified biallelic mutations in KLHL41 (kelchlike 41; MIM 607701) in five unrelated children with nemaline myopathy 9 (NEM9; MIM 615731). ${ }^{65}$ KLHL41 is a key protein in myofibre development. ${ }^{65}$ NEM9 severity ranges from neonatal death to progressive distal weakness with ambulation preserved into late childhood. ${ }^{65}$ Western blot showed reduced KLHL41 in patients compared with controls. klbl41 knockout in zebrafish caused myofibril disorganisation with nemaline body formation and impaired motor function. ${ }^{65}$ Mouse knockouts showed a marked reduction in nebulin and lesser reduction in other sarcomeric proteins. ${ }^{66}$ KLHL41 stabilises nebulin, acting as a polyubiquitin-dependent chaperone that prevents nebulin aggregation. ${ }^{66}$

\section{LMOD3}

Yuen et al identified 21 patients from 14 families with severe congenital nemaline myopathy. ${ }^{67}$ Consistent features were significant generalised hypotonia at birth, respiratory insufficiency, feeding difficulties and bulbar weakness. Most patients died of respiratory failure shortly after birth. Yuen et al identified biallelic nonsense or frameshift mutations in leiomodin 3 (LMOD3; MIM 616112), which is expressed in both the skeletal and cardiac muscles. ${ }^{67}$ Biopsies showed nemaline bodies and atrophic myofibres, and absence of LMOD3 protein in all but one patient. ${ }^{67}$ Some patients' muscle showed shortening and disorganisation of thin filaments while others had no discernible sarcomeric structure. ${ }^{67}$ Mouse knockouts showed sarcomeric disarray visible by histological staining. ${ }^{68}$ Yuen et al suggested LMOD3 is pivotal for sarcomeric thin filament stability and regulation of thin filament length. ${ }^{67}$ Cenik et al showed LMOD3 is involved in regulation of sarcomeric assembly and skeletal muscle function. ${ }^{68}$

\section{MYBPC1}

Dominant MYBPC1 (myosin-binding protein C, slow type; MIM 160794) missense mutations cause mild distal arthrogryposis $1 \mathrm{~B}$ (MIM 614335). ${ }^{16970}$ Recessive mutations cause lethal congenital contracture syndrome 4 (MIM 614915). ${ }^{70}$ Two consanguineous families from a Bedouin tribe in Israel harboured a homozygous MYBPC1 founder mutation. MYBPC1 provides thick filament stability and modulates contraction through its interactions with myosin and actin. ${ }^{71}$

\section{MYH3}

Mutations in the head and neck domains of MYH3 (myosin heavy chain, embryonic; MIM 160720) cause dominant distal arthrogryposis 2A and 2B (MIM 193700, DA2B; MIM 601680). ${ }^{1}$ Chong et al expanded the phenotype to include distal arthrogryposis 8 (MIM 178110), predominantly caused by mutations in the tail region of $\mathrm{MYH3} 3 .^{72}$ Features include pterygia, camptodactyly, vertebral fusions and scoliosis. ${ }^{72}$
MYOD1

MYOD1 (MIM 159970) encodes MyoD, a major regulator of precursor cell commitment to the myogenic differentiation pathway and repair of damaged muscle. ${ }^{73}$ Watson and colleagues ${ }^{74}$ described three patients from a consanguineous family with lethal fetal akinesia. Consistent features included third-trimester polyhydramnios, respiratory insufficiency, cleft palate and dysmorphic facial features. Variable features included pulmonary hypoplasia and diaphragmatic eventration. Exome sequencing revealed a homozygous nonsense MYOD1 variant that likely causes nonsense-mediated RNA decay. ${ }^{75}$ Mutations of MYOD1 seem to be a rare cause of fetal akinesia, since additional families are yet to be described.

\section{TTN}

TTN (MIM 188840) encodes the giant muscle protein titin, spanning from Z-disc to M-line and playing a crucial role in cardiac and skeletal muscle sarcomere assembly, structure and force transmission. ${ }^{76}$ Chauveau and colleagues ${ }^{77}$ first described TTN-related fetal akinesia caused by recessive TTN mutations. They reported a female patient with distal AMC, congenital muscle weakness, neonatal cardiac failure and bilateral camptodactyly. Muscle biopsy at 15 months was consistent with multiminicore disease. Terminal heart failure required a transplant at age 4. Fernández-Marmiesse et al described fetal hypokinesia caused by a homozygous truncating mutation in exon $197 .{ }^{76}$ This exon is absent from adult TTN isoforms, but present in the fetal 364-exon inferred complete isoform, also known as the TTN 'metatranscript' (reference sequence NM_001267550.2)..$^{76} 78$ The authors suggest cardiac muscle was spared because exon 197 is absent from the cardiac titin isoforms. ${ }^{76}$ Features included fetal hypokinesia, distal arthrogryposis, delayed motor milestones, high-arched palate and weak suction. Muscle biopsy showed persistent amyoplasia. ${ }^{76}$ A later cohort study of 30 patients with recessive congenital titinopathy showed 10 also had a mutation within TTN metatranscript-only exons. ${ }^{78}$ These mutations were suggested to affect as-yet uncharacterised developmental TTN isoforms. ${ }^{78}$

\section{ZBTB42}

Patel et al described ZBTB42 (zinc finger and BTB domain containing protein 42; MIM 616248) to cause lethal congenital contracture syndrome 6 (MIM 616248). ${ }^{79}$ A consanguineous family had three infants harbouring a homozygous ZBTB42 missense mutation. ${ }^{79}$ Zebrafish studies showed ZBTB42 is necessary for normal skeletal muscle development, with deficiency causing sarcomeric disorganisation and NMJ abnormalities. ${ }^{79}$ Zebrafish with the mutation recapitulated the patient phenotype, confirming its pathogenicity. ${ }^{79}$

\section{OTHER \\ DPAGT1}

Congenital disorders of glycosylation are increasingly recognised as a cause of complex neurogenetic malformations. ${ }^{80}$ DPAGT1 (dolichyl-phosphate N-acetylglucosamine phosphotransferase) initiates the biosynthetic pathway needed for protein N-glycosylation. ${ }^{81}$ Recessive mutations in DPAGT1 (MIM 191350) cause a range of phenotypes, from severe neonatal neurogenetic disease to muscular dystrophy. ${ }^{80}$ One patient was reported with fetal akinesia. ${ }^{80}$ Features included central respiratory depression, delayed brain myelination and hypoplasia of the inferior cerebellar vermis. ${ }^{80}$ She also had bilateral cataracts and arachnodactyly. ${ }^{80}$ 


\section{DISCUSSION}

The fetal akinesia disease spectrum encompasses several aetiologies unified by reduced or absent fetal movement. We grouped these diseases by affected tissue. In the 2011 review, no definitive peripheral nerve-related fetal akinesia genes were described. In the intervening years, eight genes have been described. Impaired axoglial function is the most common pathway, with four genes implicated (ADCY6, ADGRG6, GLDN, LGI4). Impaired muscle contractility caused by sarcomeric disarray is strongly represented in the muscle genes. Severe muscle channelopathies are a recent addition to the fetal akinesia family of genes (CACNA1S, SCN4A). Although both genes are associated with comparatively mild dominant disease, loss-of-function causes a severe phenotype, echoing DNM2, MYBPC1, RYR1, TPM2 and TTN. Many new fetal akinesia genes encode interacting partners of genes described in the 2011 review. It seems reasonable that additional genes in these pathways will become associated with neuromuscular disease.

Within rare diseases, unbiased NGS is blurring the boundaries between what were previously considered distinct clinical entities. In 2013, Boycott et al predicted many 'novel' diseases would be phenotypic expansions of known disease genes, which is a recurring theme in fetal akinesias. ${ }^{82}$ These novel genotypephenotype correlations are often surprising, and can be difficult to classify without additional cases or functional studies to confirm pathogenicity. The rise of genetic 'match-making' services such as Matchmaker Exchange ${ }^{83}$ greatly assists by providing additional cases to corroborate findings and justify further investigation. In the case of GLDN and GLE1, phenotypic expansions demonstrated mutations in these genes are not universally fatal, radically altering the prognostic landscape. The implications are far-reaching, raising questions about the universal fatality of other fetal akinesia disease genes.

Despite the power of current genetic diagnostics, variant interpretation remains challenging, even within known disease genes. Variants that cannot be definitively classified as either pathogenic or benign (variants of unknown significance) leave many patients without a genetic diagnosis. Diffusion of NGS from research into the clinic has blurred the distinction between these two realms. ${ }^{82}$ This porous boundary necessitates diagnostic labs to collaborate with researchers for functional validation. However, as diagnostic genomics integrates into mainstream healthcare, ad hoc research follow-up will become increasingly unfeasible. High-throughput functional assays will need to be developed by researchers and implemented into diagnostic pipelines for pathogenicity validation. This diagnostic functional validation should be funded as part of a 'whole of service' charge for the diagnostic testing.

An example of a successful centralised functional genomic collaboration is the Canadian Care4Rare initiative (previously Finding of Rare Disease Genes in Canada (FORGE Canada) Consortium), which established a portal to connect rare disease researchers and clinicians with fundamental biologists that have interest and particular strength in a candidate disease gene or functional assay. ${ }^{84}$ As our ability to discover variants increases, we may need high-throughput functional assays to assist with variant interpretation on a similar scale. Methods include saturation mutagenesis or multiplex assays of variant effect, which may provide functional insight into the vast depths of possible pathogenic variants. ${ }^{85}$ However, conferring clinical meaning to variants based on these assays may require additional computational approaches such as machine learning. ${ }^{85}$ Regardless of the avenue of genetic investigation, banking of patient material and/or cell lines should be performed whenever possible to facilitate follow-up functional studies. Use of patient cells or tissue for investigation is often much faster and more cost-effective than other methods, for example generating CRISPR cell lines harbouring the variant of interest or studies in model organisms. ${ }^{86}$

Other reasons many cases lack candidate variants likely include that further disease mechanisms and genes remain undiscovered or underexplored. Variants that are difficult to detect with current NGS technology may explain a proportion of unsolved cases. Genetic mosaicism contributes to monogenic disease, but the full extent is uncertain due to the difficulties in detection. ${ }^{82}$ Exome-based and short-read technology struggle to detect structural variants, duplications, deletions and repeat sequences. Although whole genome sequencing and long-read technologies can detect these variants, they are currently unaffordable for many groups. As they become more accessible, detection of this class of variants will improve. Beyond improved detection, the ability to interpret variant pathogenicity is vital. Transcriptomics can identify splicing alternations that would not have been predicted from DNA sequencing alone. This also hints at the contribution of non-coding mutations in Mendelian disease. Recent papers identified splicing defects in gene promoters and introns through combining DNA and RNA sequencing. ${ }^{87-89}$ This approach provided an answer for approximately one-third of patients in a recent study. ${ }^{87}$ However, full understanding of the role of the vast non-coding genome in Mendelian disease will take years. ${ }^{8}$ Therefore, the impact of non-exonic mutations in human disease remains somewhat controversial.

The prenatal onset in fetal akinesia combined with the high incidence of severe structural defects limits therapeutic options. ${ }^{82}$ Additionally, detection of fetal akinesia by ultrasound is poor. ${ }^{10}$ Thus, there is increasing interest in preventing severe or lethal congenital conditions via preconception carrier screening. This detects couples at risk of having a child with a severe recessive disorder before pregnancy, facilitating family planning. ${ }^{90}$ Although broad implementation of preconception carrier screening requires careful ethical and practical consideration, it is gaining credence as a viable preventative measure. $^{90}$

Acknowledgements We would like to gratefully acknowledge the family involved in this study. We also thank The Fred Liuzzi Foundation for their ongoing support, and all other funding bodies.

Contributors SJB and ML cowrote the manuscript. SJB edited and formatted the manuscript. DM and AC edited the manuscript and added clinical insight. CML edited the manuscript and provided pathological insight. MD edited the manuscript and provided diagnostic genomics insight. NGL and GR conceptualised the paper and edited the manuscript.

Funding SJB is supported by The Fred Liuzzi Foundation (Australia). NGL (APP1117510) and GR (APP1122952) are supported by the Australian NHMRC. GR is also supported by the Department of Health FutureHealth WA Merit Awards. This work is funded by The Fred Liuzzi Foundation, Association Francaise contre les Myopathies (AFM) (18724) and NHMRC (APP1080587). The funding agencies had no involvement in the design, completion or writing of this study.

Competing interests None declared.

Patient consent Not required.

Provenance and peer review Not commissioned; externally peer reviewed.

(c) Article author(s) (or their employer(s) unless otherwise stated in the text of the article) 2018. All rights reserved. No commercial use is permitted unless otherwise expressly granted. 


\section{REFERENCES}

1 Ravenscroft G, Sollis E, Charles AK, North KN, Baynam G, Laing NG. Fetal akinesia: review of the genetics of the neuromuscular causes. J Med Genet 2011;48:793-801.

2 DeMyer W, Baird I. Mortality and skeletal malformations from amniocentesis and oligohydramnios in rats: cleft palate, clubfoot, microstomia, and adactyly. Teratology $1969 ; 2: 33-7$

3 Drachman DB, Sokoloff L. The role of movement in embryonic joint development. Dev Biol 1966;14:401-20.

4 Pagnamenta AT, Howard MF, Wisniewski E, Popitsch N, Knight SJ, Keays DA, Quaghebeur G, Cox H, Cox P, Balla T, Taylor JC, Kini U. Germline recessive mutations in PI4KA are associated with perisylvian polymicrogyria, cerebellar hypoplasia and arthrogryposis. Hum Mol Genet 2015;24:3732-41.

5 Winters L, Van Hoof E, De Catte L, Van Den Bogaert K, de Ravel T, De Waele L, Corveleyn A, Breckpot J. Massive parallel sequencing identifies RAPSN and PDHA1 mutations causing fetal akinesia deformation sequence. Eur J Paediatr Neurol 2017:21:745-53.

6 Kurolap A, Armbruster A, Hershkovitz T, Hauf K, Mory A, Paperna T, Hannappel E, Tal G, Nijem Y, Sella E, Mahajnah M, llivitzki A, Hershkovitz D, Ekhilevitch N, Mandel $\mathrm{H}$, Eulenburg V, Baris HN. Loss of glycine transporter 1 causes a subtype of glycine encephalopathy with arthrogryposis and mildly elevated cerebrospinal fluid glycine. Am J Hum Genet 2016;99:1172-80.

7 Ravenscroft G, Laing NG, Bönnemann CG. Pathophysiological concepts in the congenital myopathies: blurring the boundaries, sharpening the focus. Brain 2015;138:246-68.

8 Ravenscroft G, Davis MR, Lamont P, Forrest A, Laing NG. New era in genetics of early-onset muscle disease: Breakthroughs and challenges. Semin Cell Dev Biol 2017;64:160-70.

9 Laing NG. Genetics of neuromuscular disorders. Crit Rev Clin Lab Sci 2012;49:33-48.

10 Filges I, Hall JG. Failure to identify antenatal multiple congenital contractures and fetal akinesia--proposal of guidelines to improve diagnosis. Prenat Diagn 2013;33:61-74.

11 Filges I, Hall JG. We are failing to identify disorders of fetal movement--why? Prenat Diagn 2012;32:919-20.

12 Stals KL, Wakeling M, Baptista J, Caswell R, Parrish A, Rankin J, Tysoe C, Jones G, Gunning AC, Lango Allen H, Bradley L, Brady AF, Carley H, Carmichael J, Castle B, Cilliers D, Cox H, Deshpande C, Dixit A, Eason J, Elmslie F, Fry AE, Fryer A, Holder M, Homfray T, Kivuva E, McKay V, Newbury-Ecob R, Parker M, Savarirayan R, Searle C, Shannon N, Shears D, Smithson S, Thomas E, Turnpenny PD, Varghese V, Vasudevan P, Wakeling E, Baple EL, Ellard S. Diagnosis of lethal or prenatal-onset autosomal recessive disorders by parental exome sequencing. Prenat Diagn 2018;38.

13 Saunders CJ, Miller NA, Soden SE, Dinwiddie DL, Noll A, Alnadi NA, Andraws N, Patterson ML, Krivohlavek LA, Fellis J, Humphray S, Saffrey P, Kingsbury Z, Weir JC, Betley J, Grocock RJ, Margulies EH, Farrow EG, Artman M, Safina NP, Petrikin JE, Hall $\mathrm{KP}$, Kingsmore SF. Rapid whole-genome sequencing for genetic disease diagnosis in neonatal intensive care units. Sci Trans/ Med 2012;4:154ra135-27.

14 Petrikin JE, Cakici JA, Clark M, Willig L, Sweeney N, Farrow E, Saunders C, Thiffault I, Miller N, Zellmer L, Herd S, Holmes A, Batalov S, Veeraraghavan N, Smith L, Dimmock D, Leeder S, Kingsmore SF. The NSIGHT1 Randomized Controlled Trial: Rapid Whole Genome Sequencing for Accelerated Etiologic Diagnosis in Critically III Infants. bioRxiv Published Online First: 1 January 2017. http://biorxiv.org/content/early/2017/11/13/ 218255

15 Deem MJ. Whole-Genome Sequencing and Disability in the NICU: Exploring Practical and Ethical Challenges. Pediatrics 2016;137(Suppl 1):S47-55.

16 Lebenthal E, Shochet SB, Adam A, Seelenfreund M, Fried A, Najenson T, Sandbank U, Matoth Y. Arthrogryposis multiplex congenita: twenty-three cases in an Arab kindred. Pediatrics 1970;46:891-9.

17 Reinstein E, Drasinover V, Lotan R, Gal-Tanamy M, Bolocan Nachman I, Eyal E, Jaber L, Magal N, Shohat M. Mutations in ERGIC1 cause Arthrogryposis multiplex congenita, neuropathic type. Clin Genet 2018;93:160-3.

18 Smith C, Parboosingh JS, Boycott KM, Bönnemann CG, Mah JK, Lamont RE, Micheil Innes A, Bernier FP. Care4Rare Canada Consortium. Expansion of the GLE1-associated arthrogryposis multiplex congenita clinical spectrum. Clin Genet 2017;91:426-30.

19 Qk-g T, McConkie-Rosell A, Juusola J, Gustafson KE, Pizoli CE, Buckley AF, Jiang Y-H. The importance of managing the patient and not the gene: expanded phenotype of GLE1 -associated arthrogryposis. Mol Case Stud 2017;3:1-10.

20 Said E, Chong JX, Hempel M, Denecke J, Soler P, Strom T, Nickerson DA, Kubisch C, Bamshad MJ, Lessel D. University of Washington Center for Mendelian Genomics. Survival beyond the perinatal period expands the phenotypes caused by mutations in GLE1. Am J Med Genet A 2017;173:3098-103.

21 Bahi-Buisson N, Poirier K, Fourniol F, Saillour Y, Valence S, Lebrun N, Hully M, Bianco CF, Boddaert N, Elie C, Lascelles K, Souville I, Beldjord C, Chelly J. LIS-Tubulinopathies Consortium. The wide spectrum of tubulinopathies: what are the key features for the diagnosis? Brain 2014;137:1676-700

22 Laquerriere A, Gonzales M, Saillour Y, Cavallin M, Joyē N, Quēlin C, Bidat L, Dommergues M, Plessis G, Encha-Razavi F, Chelly J, Bahi-Buisson N, Poirier K. De novo TUBB2B mutation causes fetal akinesia deformation sequence with microlissencephaly: An unusual presentation of tubulinopathy. Eur J Med Genet 2016;59:249-56.
23 Knierim E, Hirata H, Wolf NI, Morales-Gonzalez S, Schottmann G, Tanaka Y, RudnikSchöneborn S, Orgeur M, Zerres K, Vogt S, van Riesen A, Gill E, Seifert F, Zwirner A, Kirschner J, Goebel HH, Hübner C, Stricker S, Meierhofer D, Stenzel W, Schuelke M. Mutations in Subunits of the Activating Signal Cointegrator 1 Complex Are Associated with Prenatal Spinal Muscular Atrophy and Congenital Bone Fractures. Am J Hum Genet 2016:98:473-89.

24 Davignon L, Chauveau C, Julien C, Dill C, Duband-Goulet I, Cabet E, Buendia B, Lilienbaum A, Rendu J, Minot MC, Guichet A, Allamand V, Vadrot N, Fauré J, Odent S, Lazaro L, Leroy JP, Marcorelles P, Dubourg O, Ferreiro A. The transcription coactivator ASC- 1 is a regulator of skeletal myogenesis, and its deficiency causes a novel form of congenital muscle disease. Hum Mol Genet 2016;25:1559-73.

25 Oliveira J, Martins M, Pinto Leite R, Sousa M, Santos R. The new neuromuscular disease related with defects in the ASC-1 complex: report of a second case confirms ASCC1 involvement. Clin Genet 2017;92:434-9.

26 Hengel H, Magee A, Mahanjah M, Vallat J-M, Ouvrier R, Abu-Rashid M, Mahamid J, Schüle R, Schulze M, Krägeloh-Mann I, Bauer P, Züchner S, Sharkia R, Schöls L. CNTNAP1 mutations cause CNS hypomyelination and neuropathy with or without arthrogryposis. Neurol Genet 2017;3:e144-7.

27 Laquérriere A, Maluenda J, Camus A, Fontenas L, Dieterich K, Nolent F, Zhou J, Monnier N, Latour P, Gentil D, Héron D, Desguerres I, Landrieu P, Beneteau C, Delaporte B, Bellesme C, Baumann C, Capri Y, Goldenberg A, Lyonnet S, Bonneau D, Estournet B, Quijano-Roy S, Francannet C, Odent S, Saint-Frison MH, Sigaudy S, Figarella-Branger D, Gelot A, Mussini JM, Lacroix C, Drouin-Garraud V, Malinge MC, Attié-Bitach T, Bessieres B, Bonniere M, Encha-Razavi F, Beaufrère AM, Khung-Savatovsky S, Perez MJ, Vasiljevic A, Mercier S, Roume J, Trestard L, Saugier-Veber $\mathrm{P}$, Cordier MP, Layet $\mathrm{V}$, Legendre M, Vigouroux-Castera A, Lunard J, Bayes M, Jouk PS, Rigonnot L, Granier M, Sternberg D, Warszawski J, Gut I, Gonzales M, Tawk M, Melki J. Mutations in CNTNAP1 and ADCY6 are responsible for severe arthrogryposis multiplex congenita with axoglial defects. Hum Mol Genet 2014; $23: 2279-89$

28 Xue S, Maluenda J, Marguet F, Shboul M, Quevarec L, Bonnard C, Ng AY, Tohari S, Tan TT, Kong MK, Monaghan KG, Cho MT, Siskind CE, Sampson JB, Rocha CT, Alkazaleh F, Gonzales M, Rigonnot L, Whalen S, Gut M, Gut I, Bucourt M, Venkatesh B, Laquerrière A, Reversade B, Melki J. Loss-of-function mutations in LGI4, a secreted ligand involved in schwann cell myelination, are responsible for arthrogryposis multiplex congenita. Am J Hum Genet 2017;100:659-65.

29 Ravenscroft G, Nolent F, Rajagopalan S, Meireles AM, Paavola KJ, Gaillard D, Alanio E, Buckland M, Arbuckle S, Krivanek M, Maluenda J, Pannell S, Gooding R, Ong RW, Allcock RJ, Carvalho ED, Carvalho MD, Kok F, Talbot WS, Melki J, Laing NG. Mutations of GPR126 are responsible for severe arthrogryposis multiplex congenita. Am J Hum Genet 2015:96:955-61.

30 Monk KR, Oshima K, Jörs S, Heller S, Talbot WS. Gpr126 is essential for peripheral nerve development and myelination in mammals. Development 2011;138:2673-80

31 McMillin MJ, Below JE, Shively KM, Beck AE, Gildersleeve HI, Pinner J, Gogola GR, Hecht JT, Grange DK, Harris DJ, Earl DL, Jagadeesh S, Mehta SG, Robertson SP, Swanson JM, Faustman EM, Mefford HC, Shendure J, Nickerson DA, Bamshad MJ. University of Washington Center for Mendelian Genomics. Mutations in ECEL1 cause distal arthrogryposis type 5D. Am J Hum Genet 2013;92:150-6.

32 Dieterich K, Quijano-Roy S, Monnier N, Zhou J, Fauré J, Smirnow DA, Carlier R, Laroche C, Marcorelles P, Mercier S, Mégarbané A, Odent S, Romero N, Sternberg D, Marty I, Estournet B, Jouk PS, Melki J, Lunardi J. The neuronal endopeptidase ECEL1 is associated with a distinct form of recessive distal arthrogryposis. Hum Mol Genet 2013;22:1483-92.

33 Dohrn N, Le VQ, Petersen A, Skovbo P, Pedersen IS, Ernst A, Krarup H, Petersen MB. ECEL1 mutation causes fetal arthrogryposis multiplex congenita. Am J Med Genet $A$ 2015; 167A:731-43.

34 Matsumoto S, Kiryu-Seo S, Kiyama H. Motor nerve arborization requires proteolytic domain of damage-induced neuronal Endopeptidase (DINE) during Development. J Neurosci 2016:36:4744-57

35 Nagata K, Kiryu-Seo S, Tamada H, Okuyama-Uchimura F, Kiyama H, Saido TC. ECEL1 mutation implicates impaired axonal arborization of motor nerves in the pathogenesis of distal arthrogryposis. Acta Neuropathol 2016;132:111-26.

36 Maluenda J, Manso C, Quevarec L, Vivanti A, Marguet F, Gonzales M, Guimiot F, Petit $F$, Toutain A, Whalen $S$, Grigorescu R, Coeslier AD, Gut M, Gut I, Laquerrière A, Devaux J, Melki J. Mutations in GLDN, encoding gliomedin, a critical component of the nodes of ranvier, are responsible for lethal arthrogryposis. Am J Hum Genet 2016;99:928-33.

37 Wambach JA, Stettner GM, Haack TB, Writzl K, Škofljanec A, Maver A, Munell F, Ossowski S, Bosio M, Wegner DJ, Shinawi M, Baldridge D, Alhaddad B, Strom TM, Grange DK, Wilichowski E, Troxell R, Collins J, Warner BB, Schmidt RE, Pestronk A, Cole FS, Steinfeld R. Survival among children with "Lethal" congenital contracture syndrome 11 caused by novel mutations in the gliomedin gene (GLDN). Hum Mutat 2017;38:1477-84

38 Coste B, Houge G, Murray MF, Stitziel N, Bandell M, Giovanni MA, Philippakis A, Hoischen A, Riemer G, Steen U, Steen VM, Mathur J, Cox J, Lebo M, Rehm H, Weiss ST, Wood JN, Maas RL, Sunyaev SR, Patapoutian A. Gain-of-function mutations in the mechanically activated ion channel PIEZO2 cause a subtype of Distal Arthrogryposis. Proc Natl Acad Sci U SA 2013;110:4667-72. 
39 Bamshad M, Van Heest AE, Pleasure D. Arthrogryposis: a review and update. J Bone Joint Surg Am 2009;91(Suppl 4):40-6.

40 McMillin MJ, Beck AE, Chong JX, Shively KM, Buckingham KJ, Gildersleeve HI, Aracena MI, Aylsworth AS, Bitoun P, Carey JC, Clericuzio CL, Crow YJ, Curry CJ, Devriendt K, Everman DB, Fryer A, Gibson K, Giovannucci Uzielli ML, Graham JM, Hall JG, Hecht JT, Heidenreich RA, Hurst JA, Irani S, Krapels IP, Leroy JG, Mowat D, Plant GT, Robertson SP, Schorry EK, Scott RH, Seaver LH, Sherr E, Splitt M, Stewart H, Stumpel C, Temel SG, Weaver DD, Whiteford M, Williams MS, Tabor HK, Smith JD, Shendure J, Nickerson DA Bamshad MJ. University of Washington Center for Mendelian Genomics. Mutations in PIEZO2 cause gordon syndrome, marden-walker syndrome, and distal arthrogryposis type 5. Am J Hum Genet 2014;94:734-44.

41 Haliloglu G, Becker K, Temucin C, Talim B, Küçükşahin N, Pergande M, Motameny S, Nürnberg P, Aydingoz U, Topaloglu H, Cirak S. Recessive PIEZO2 stop mutation causes distal arthrogryposis with distal muscle weakness, scoliosis and proprioception defects. J Hum Genet 2017;62:497-501.

42 Chesler AT, Szczot M, Bharucha-Goebel D, Čeko M, Donkervoort S, Laubacher C, Hayes LH, Alter K, Zampieri C, Stanley C, Innes AM, Mah JK, Grosmann CM, Bradley N, Nguyen D, Foley AR, Le Pichon CE, Bönnemann CG. The Role of PIEZO2 in Human Mechanosensation. N Engl J Med 2016:375:1355-64.

43 Mahmud AA, Nahid NA, Nassif C, Sayeed MS, Ahmed MU, Parveen M, Khalil MI, Islam MM, Nahar Z, Rypens F, Hamdan FF, Rouleau GA, Hasnat A, Michaud JL. Loss of the proprioception and touch sensation channel PIEZO2 in siblings with a progressive form of contractures. Clin Genet 2017;91:470-5.

44 Delle Vedove A, Storbeck M, Heller R, Hölker I, Hebbar M, Shukla A, Magnusson O, Cirak S, Girisha KM, O'Driscoll M, Loeys B, Wirth B. Biallelic loss of proprioceptionrelated PIEZO2 causes muscular atrophy with perinatal respiratory distress, arthrogryposis, and scoliosis. Am J Hum Genet 2016;99:1206-16.

45 Tan-Sindhunata MB, Mathijssen IB, Smit M, Baas F, de Vries JI, van der Voorn JP, Kluijt I, Hagen MA, Blom EW, Sistermans E, Meijers-Heijboer H, Waisfisz Q, Weiss MM, Groffen AJ. Identification of a Dutch founder mutation in MUSK causing fetal akinesia deformation sequence. Eur J Hum Genet 2015;23:1151-7.

46 Wilbe M, Ekvall S, Eurenius K, Ericson K, Casar-Borota O, Klar J, Dahl N, Ameur A, Annerén G, Bondeson ML. MuSK: a new target for lethal fetal akinesia deformation sequence (FADS). J Med Genet 2015;52:195-202.

47 Aran A, Segel R, Kaneshige K, Gulsuner S, Renbaum P, Oliphant S, Meirson T, Weinberg-Shukron A, Hershkovitz Y, Zeligson S, Lee MK, Samson AO, Parsons SM, King MC, Levy-Lahad E, Walsh T. Vesicular acetylcholine transporter defect underlies devastating congenital myasthenia syndrome. Neurology 2017;88:1021-8.

48 Abiusi E, D'Alessandro M, Dieterich K, Quevarec L, Turczynski S, Valfort AC, Mezin P, Jouk PS, Gut M, Gut I, Bessereau JL, Melki J. Biallelic mutation of UNC50, encoding a protein involved in AChR trafficking, is responsible for arthrogryposis. Hum Mol Genet 2017;26:3989-94.

49 Schartner V, Romero NB, Donkervoort S, Treves S, Munot P, Pierson TM, Dabaj I, Malfatti E, Zaharieva IT, Zorzato F, Abath Neto O, Brochier G, Lornage X, Eymard B, Taratuto AL, Böhm J, Gonorazky H, Ramos-Platt L, Feng L, Phadke R, BharuchaGoebel DX, Sumner CJ, Bui MT, Lacene E, Beuvin M, Labasse C, Dondaine N, Schneider R, Thompson J, Boland A, Deleuze JF, Matthews E, Pakleza AN, Sewry CA, Biancalana V, Quijano-Roy S, Muntoni F, Fardeau M, Bönnemann CG, Laporte J. Dihydropyridine receptor (DHPR, CACNA1S) congenital myopathy. Acta Neuropathol 2017:133:517-33

50 Bitoun M, Maugenre S, Jeannet PY, Lacène E, Ferrer X, Laforêt P, Martin JJ, Laporte J, Lochmüller H, Beggs AH, Fardeau M, Eymard B, Romero NB, Guicheney P. Mutations in dynamin 2 cause dominant centronuclear myopathy. Nat Genet 2005;37:1207-9.

51 Böhm J, Biancalana V, Dechene ET, Bitoun M, Pierson CR, Schaefer E, Karasoy H, Dempsey MA, Klein F, Dondaine N, Kretz C, Haumesser N, Poirson C, Toussaint A, Greenleaf RS, Barger MA, Mahoney LJ, Kang PB, Zanoteli E, Vissing J, Witting N, Echaniz-Laguna A, Wallgren-Pettersson C, Dowling J, Merlini L, Oldfors A, Bomme Ousager L, Melki J, Krause A, Jern C, Oliveira AS, Petit F, Jacquette A, Chaussenot A, Mowat D, Leheup B, Cristofano M, Poza Aldea JJ, Michel F, Furby A, Llona JE, Van Coster R, Bertini E, Urtizberea JA, Drouin-Garraud V, Béroud C, Prudhon B, Bedford M, Mathews K, Erby LA, Smith SA, Roggenbuck J, Crowe CA, Brennan Spitale A, Johal SC, Amato AA, Demmer LA, Jonas J, Darras BT, Bird TD, Laurino M, Welt SI, Trotter C, Guicheney P, Das S, Mandel JL, Beggs AH, Laporte J. Mutation spectrum in the large GTPase dynamin 2, and genotype-phenotype correlation in autosomal dominant centronuclear myopathy. Hum Mutat 2012;33:949-59.

52 Züchner S, Noureddine M, Kennerson M, Verhoeven K, Claeys K, De Jonghe P, Merory J, Oliveira SA, Speer MC, Stenger JE, Walizada G, Zhu D, Pericak-Vance MA, Nicholson G, Timmerman V, Vance JM. Mutations in the pleckstrin homology domain of dynamin 2 cause dominant intermediate Charcot-Marie-Tooth disease. Nat Genet 2005:37:289-94.

53 Koutsopoulos OS, Kretz C, Weller CM, Roux A, Mojzisova H, Böhm J, Koch C, Toussaint A, Heckel E, Stemkens D, Ter Horst SA, Thibault C, Koch M, Mehdi SQ, Bijlsma EK, Mandel JL, Vermot J, Laporte J. Dynamin 2 homozygous mutation in humans with a lethal congenital syndrome. Eur J Hum Genet 2013;21:637-42.

54 Chang W, Winder TL, LeDuc CA, Simpson LL, Millar WS, Dungan J, Ginsberg N, Plaga S, Moore SA, Chung WK. Founder fukutin mutation causes walker-warburg syndrome in four ashkenazi jewish families. Prenat Diagn 2009;29:560-9.

55 Jaeken J, Péanne R. What is new in CDG? J Inherit Metab Dis 2017:1-17.
56 Willer T, Lee H, Lommel M, Yoshida-Moriguchi T, de Bernabe DB, Venzke D, Cirak S, Schachter H, Vaisar J, Voit T, Muntoni F, Loder AS, Dobyns WB, Winder TL, Strahl S, Mathews KD, Nelson SF, Moore SA, Campbell KP. ISPD loss-of-function mutations disrupt dystroglycan 0-mannosylation and cause Walker-Warburg syndrome. Nat Genet 2012;44:575-80.

57 Murakami T, Hayashi YK, Noguchi S, Ogawa M, Nonaka I, Tanabe Y, Ogino M, Takada F, Eriguchi M, Kotooka N, Campbell KP, Osawa M, Nishino I. Fukutin gene mutations cause dilated cardiomyopathy with minimal muscle weakness. Ann Neurol 2006:60:597-602

58 Trimmer JS, Cooperman SS, Tomiko SA, Zhou JY, Crean SM, Boyle MB, Kallen RG, Sheng ZH, Barchi RL, Sigworth FJ, Goodman RH, Agnew WS, Mandel G. Primary structure and functional expression of a mammalian skeletal muscle sodium channel. Neuron 1989:3:33-49.

59 Zaharieva IT, Thor MG, Oates EC, van Karnebeek C, Hendson G, Blom E, Witting N, Rasmussen M, Gabbett MT, Ravenscroft G, Sframeli M, Suetterlin K, Sarkozy A, D’Argenzio L, Hartley L, Matthews E, Pitt M, Vissing J, Ballegaard M, Krarup C, Slørdahl A, Halvorsen H, Ye XC, Zhang LH, Løkken N, Werlauff U, Abdelsayed M, Davis MR, Feng L, Phadke R, Sewry CA, Morgan JE, Laing NG, Vallance H, Ruben P, Hanna MG, Lewis S, Kamsteeg EJ, Männikkö R, Muntoni F. Loss-of-function mutations in SCN4A cause severe foetal hypokinesia or 'classical' congenital myopathy. Brain 2016;139:674-91.

60 Konialis C, Assimakopoulos E, Hagnefelt B, Karapanou S, Sotiriadis A, Pangalos C. Prenatal diagnosis of $X$-linked myopathy associated with a VMA21 gene mutation afforded through a novel targeted exome sequencing strategy applied in fetuses with abnormal ultrasound findings. Clin Case Rep 2017;5:308-11.

61 Yan C, Tanaka M, Sugie K, Nobutoki T, Woo M, Murase N, Higuchi Y, Noguchi S, Nonaka I, Hayashi YK, Nishino I. A new congenital form of X-linked autophagic vacuolar myopathy. Neurology 2005;65:1132-4.

62 Ruggieri A, Ramachandran N, Wang P, Haan E, Kneebone C, Manavis J, Morandi L, Moroni I, Blumbergs P, Mora M, Minassian BA. Non-coding VMA21 deletions cause X-linked myopathy with excessive autophagy. Neuromuscul Disord 2015;25:207-11.

63 Ravenscroft G, Miyatake S, Lehtokari VL, Todd EJ, Vornanen P, Yau KS, Hayashi YK, Miyake N, Tsurusaki Y, Doi H, Saitsu H, Osaka H, Yamashita S, Ohya T, Sakamoto Y, Koshimizu E, Imamura S, Yamashita M, Ogata K, Shiina M, Bryson-Richardson RJ, Vaz R, Ceyhan O, Brownstein CA, Swanson LC, Monnot S, Romero NB, Amthor H, Kresoje N, Sivadorai P, Kiraly-Borri C, Haliloglu G, Talim B, Orhan D, Kale G, Charles AK, Fabian VA, Davis MR, Lammens M, Sewry CA, Manzur A, Muntoni F, Clarke NF, North KN, Bertini E, Nevo Y, Willichowski E, Silberg IE, Topaloglu H, Beggs AH, Allcock RJ, Nishino I, Wallgren-Pettersson C, Matsumoto N, Laing NG. Mutations in KLHL40 are a frequent cause of severe autosomal-recessive nemaline myopathy. Am I Hum Genet 2013:93:6-18.

64 Garg A, O'Rourke J, Long C, Doering J, Ravenscroft G, Bezprozvannaya S, Nelson BR, Beetz N, Li L, Chen S, Laing NG, Grange RW, Bassel-Duby R, Olson EN. KLHL40 deficiency destabilizes thin filament proteins and promotes nemaline myopathy. J Clin Invest 2014;124:3529-39.

65 Gupta VA, Ravenscroft G, Shaheen R, Todd EJ, Swanson LC, Shiina M, Ogata K, Hsu C, Clarke NF, Darras BT, Farrar MA, Hashem A, Manton ND, Muntoni F, North KN, Sandaradura SA, Nishino I, Hayashi YK, Sewry CA, Thompson EM, Yau KS, Brownstein CA, Yu TW, Allcock RJ, Davis MR, Wallgren-Pettersson C, Matsumoto N, Alkuraya FS, Laing NG, Beggs AH. Identification of KLHL41 mutations implicates BTB-Kelchmediated ubiquitination as an alternate pathway to myofibrillar disruption in nemaline myopathy. Am J Hum Genet 2013;93:1108-17.

66 Ramirez-Martinez A, Cenik BK, Bezprozvannaya S, Chen B, Bassel-Duby R, Liu $\mathrm{N}$, Olson EN. KLHL41 stabilizes skeletal muscle sarcomeres by nonproteolytic ubiquitination. Elife 2017;6:1-24.

67 Yuen M, Sandaradura SA, Dowling JJ, Kostyukova AS, Moroz N, Quinlan KG, Lehtokari VL, Ravenscroft G, Todd EJ, Ceyhan-Birsoy O, Gokhin DS, Maluenda J, Lek M, Nolent F, Pappas CT, Novak SM, D'Amico A, Malfatti E, Thomas BP, Gabriel SB, Gupta N, Daly MJ, Ilkovski B, Houweling PJ, Davidson AE, Swanson LC, Brownstein CA, Gupta VA, Medne L, Shannon P, Martin N, Bick DP, Flisberg A, Holmberg E, Van den Bergh P, Lapunzina P, Waddell LB, Sloboda DD, Bertini E, Chitayat D, Telfer WR, Laquerrière A, Gregorio CC, Ottenheijm CA, Bönnemann CG, Pelin K, Beggs AH, Hayashi YK, Romero NB, Laing NG, Nishino I, Wallgren-Pettersson C, Melki J, Fowler VM, MacArthur DG, North KN, Clarke NF. Leiomodin-3 dysfunction results in thin filament disorganization and nemaline myopathy. J Clin Invest 2014;124:4693-708.

68 Cenik BK, Garg A, McAnally JR, Shelton JM, Richardson JA, Bassel-Duby R, Olson EN, Liu N. Severe myopathy in mice lacking the MEF2/SRF-dependent gene leiomodin-3. J Clin Invest 2015:125:1569-78.

69 Gurnett CA, Desruisseau DM, McCall K, Choi R, Meyer ZI, Talerico M, Miller SE, Ju JS, Pestronk A, Connolly AM, Druley TE, Weihl CC, Dobbs MB. Myosin binding protein C1: a novel gene for autosomal dominant distal arthrogryposis type 1. Hum Mol Genet 2010;19:1165-73.

70 Markus B, Narkis G, Landau D, Birk RZ, Cohen I, Birk OS. Autosomal recessive lethal congenital contractural syndrome type 4 (LCCS4) caused by a mutation in MYBPC1. Hum Mutat 2012;33:1435-8.

71 Ha K, Buchan JG, Alvarado DM, McCall K, Vydyanath A, Luther PK, Goldsmith MI, Dobbs MB, Gurnett CA. MYBPC1 mutations impair skeletal muscle function in zebrafish models of arthrogryposis. Hum Mol Genet 2013;22:4967-77. 
72 Chong JX, Burrage LC, Beck AE, Marvin CT, McMillin MJ, Shively KM, Harrell TM, Buckingham KJ, Bacino CA, Jain M, Alanay Y, Berry SA, Carey JC, Gibbs RA, Lee BH, Krakow D, Shendure J, Nickerson DA, Bamshad MJ. University of Washington Center for Mendelian Genomics. Autosomal-dominant multiple pterygium syndrome is caused by mutations in MYH3. Am J Hum Genet 2015;96:841-9.

73 Guttridge DC, Mayo MW, Madrid LV, Wang CY, Baldwin AS. NF-kappaB-induced loss of MyoD messenger RNA: possible role in muscle decay and cachexia. Science 2000;289:2363-6.

74 Auton A, Brooks LD, Durbin RM, Garrison EP, Kang HM, Korbel JO, Marchini JL, McCarthy S, McVean GA, Abecasis GR. 1000 Genomes Project Consortium. A global reference for human genetic variation. Nature 2015;526:68-74.

75 Watson CM, Crinnion LA, Murphy H, Newbould M, Harrison SM, Lascelles C, Antanaviciute A, Carr IM, Sheridan E, Bonthron DT, Smith A. Deficiency of the myogenic factor MyoD causes a perinatally lethal fetal akinesia. J Med Genet 2016:53:264-9.

76 Fernández-Marmiesse A, Carrascosa-Romero MC, Alfaro Ponce B, Nascimento A, Ortez C, Romero N, Palacios L, Jimenez-Mallebrera C, Jou C, Gouveia S, Couce ML. Homozygous truncating mutation in prenatally expressed skeletal isoform of TTN gene results in arthrogryposis multiplex congenita and myopathy without cardiac involvement. Neuromuscul Disord 2017;27:188-92.

77 Chauveau C, Bonnemann CG, Julien C, Kho AL, Marks H, Talim B, Maury P, Arne-Bes MC, Uro-Coste E, Alexandrovich A, Vihola A, Schafer S, Kaufmann B, Medne L, Hübner N, Foley AR, Santi M, Udd B, Topaloglu H, Moore SA, Gotthardt M, Samuels ME, Gautel M, Ferreiro A. Recessive TTN truncating mutations define novel forms of core myopathy with heart disease. Hum Mol Genet 2014;23:980-91.

78 Oates E, Yau K, Jones K, Smith J, Cummings B, Farrar M, Cooper S, Lek M, Hoffman E, Straub V, Ferreiro A, Udd B, Beggs A, Bönnemann C, North K, MacArthur D, Granzier H, Muntoni F, Davis M, Laing N. Do titin developmental isoforms contribute to the pathogenesis of congenital titinopathy? Neuromuscular Disorders 2017;27:S237-S238.

79 Patel N, Smith LL, Faqeih E, Mohamed J, Gupta VA, Alkuraya FS. ZBTB42 mutation defines a novel lethal congenital contracture syndrome (LCCS6). Hum Mol Genet 2014;23:6584-93.

80 Ganetzky R, Izumi K, Edmondson A, Muraresku CC, Zackai E, Deardorff M, Ganesh J. Fetal akinesia deformation sequence due to a congenital disorder of glycosylation. Am J Med Genet A 2015;167A:2411-7.

81 Würde AE, Reunert J, Rust S, Hertzberg C, Haverkämper S, Nürnberg G, Nürnberg P, Lehle L, Rossi R, Marquardt T. Congenital disorder of glycosylation type lj (CDG-lj,
DPAGT1-CDG): extending the clinical and molecular spectrum of a rare disease. Mol Genet Metab 2012;105:634-41.

82 Boycott KM, Vanstone MR, Bulman DE, MacKenzie AE. Rare-disease genetics in the era of next-generation sequencing: discovery to translation. Nat Rev Genet 2013; 14:681-91

83 Philippakis AA, Azzariti DR, Beltran S, Brookes AJ, Brownstein CA, Brudno M, Brunner HG, Buske OJ, Carey K, Doll C, Dumitriu S, Dyke SO, den Dunnen JT, Firth HV, Gibbs RA, Girdea M, Gonzalez M, Haendel MA, Hamosh A, Holm IA, Huang L, Hurles ME, Hutton B, Krier JB, Misyura A, Mungall CJ, Paschall J, Paten B, Robinson PN, Schiettecatte F, Sobreira NL, Swaminathan GJ, Taschner PE, Terry SF, Washington NL, Züchner S, Boycott KM, Rehm HL. The Matchmaker Exchange: a platform for rare disease gene discovery. Hum Mutat 2015;36:915-21.

84 Foley KE. Model network: Canadian program aims to generate models for rare disease. Nat Med 2015;21:1242-3.

85 Starita LM, Ahituv N, Dunham MJ, Kitzman JO, Roth FP, Seelig G, Shendure J, Fowler DM. Variant interpretation: functional assays to the rescue. Am J Hum Genet 2017; 101:315-25.

86 Wang H, Yang H, Shivalila CS, Dawlaty MM, Cheng AW, Zhang F, Jaenisch R. One-step generation of mice carrying mutations in multiple genes by CRISPR/Cas-mediated genome engineering. Cell 2013;153:910-8.

87 Cummings BB, Marshall JL, Tukiainen T, Lek M, Donkervoort S, Foley AR, Bolduc V, Waddell LB, Sandaradura SA, O'Grady GL, Estrella E, Reddy HM, Zhao F, Weisburd B, Karczewski KJ, O'Donnell-Luria AH, Birnbaum D, Sarkozy A, Hu Y, Gonorazky H, Claeys K, Joshi H, Bournazos A, Oates EC, Ghaoui R, Davis MR, Laing NG, Topf A Kang PB, Beggs AH, North KN, Straub V, Dowling JJ, Muntoni F, Clarke NF, Cooper ST, Bönnemann CG, MacArthur DG. Genotype-Tissue Expression Consortium. Improving genetic diagnosis in Mendelian disease with transcriptome sequencing. Sci Trans/ Med 2017;9:eaal5209-25.

88 Gonorazky H, Liang M, Cummings B, Lek M, Micallef J, Hawkins C, Basran R, Cohn R, Wilson MD, MacArthur D, Marshall CR, Ray PN, Dowling JJ. RNAseq analysis for the diagnosis of muscular dystrophy. Ann Clin Trans/ Neurol 2016;3:55-60.

89 Ilkovski B, Pagnamenta AT, O'Grady GL, Kinoshita T, Howard MF, Lek M, Thomas B, Turner A, Christodoulou J, Sillence D, Knight SJ, Popitsch N, Keays DA, Anzilotti C, Goriely A, Waddell LB, Brilot F, North KN, Kanzawa N, Macarthur DG, Taylor JC, Kini U, Murakami Y, Clarke NF. Mutations in PIGY: expanding the phenotype of inherited glycosylphosphatidylinositol deficiencies. Hum Mol Genet 2015;24:6146-59.

90 American College of Obstetricians and Gynecologists (ACOG). Carrier screening for genetic conditions. Committee opinion no. 691. Obstet Gynecol 2017;129:1-15. 